\title{
Difference in The Influence of Practice Regulating Passes and Regulating The Game Against The Accuracy of Passing in Junior Football Players
}

\author{
Marshal Ahmad Sibarani ${ }^{\text {a }}$, Jack Suman Rulis Manurung ${ }^{\text {b }}$ \\ ${ }^{a}$ Physical Education of Health and Recreation, Sekolah Tinggi Olahraga dan Kesehatan Bina \\ Guna Medan \\ ${ }^{b}$ STKIP Pamane Talino \\ marshalsibarani@gmail.com $^{\text {a, }}$, jack.surru@gmail.com $^{\text {b }}$
}

\begin{abstract}
This research aims to find out what exercises are more influential between the practice of regulating passes and the practice of regulating the game against the accuracy of passing in football games in The Extracurricular Students of Private Elementary School Al Wasliyah 30 Martubung Medan In 2021. Participants in this study as many as 20 students with an age range of 10-12 years. Research design is pre-test two group experimental design. This research instrument is a test of passing accuracy in a piece of football. Quantitative descriptive analysis of data, by comparing differences in pretest and postest results. The results of the study in the form of analysis of two research hypotheses. Analysis of the first hypothesis of pre-test data and post-test accuracy of passing ball pass exercise group according obtained $t_{\text {hitung }}=6.86$. From the list of distributions $t$ using the odds of $1-1 / 2 \alpha=0.975$ with degree of freedom (df) $n-1$ $=9$ obtained $t_{\text {count }}(0.975)=2.26$. In the hypothesis testing criteria it is stated that in $\mathrm{t}_{\text {count }}>\mathrm{t}_{\text {table }}$ with $\alpha=0.05$ then Ho accepted Ha rejected. Analysis of the second hypothesis of pre-test data and post-test accuracy of passing ball of the Set Passen exercise group obtained $t_{\text {count }}=5.43$. From the list of distributions $t$ using the odds of $1-1 / 2 \alpha=0.975$ with df $n-1=9$ obtained the price $t(0.975)=2.26$. In the hypothesis testing criteria it is stated that in $t_{\text {count }}>t_{\text {count }}$ with $\alpha=0.05$ then Ho rejected Ha accepted. Then it can be concluded by using the form of practice of regulating passes and arranging the game can improve the accuracy of passing in football games in The Private Elementary School Football Extracurricular Student Al Wasliyah 30 Martubung Medan Year 2021. This research contributes to subsequent research by being able to use other variables as treatment in the accuracy of football passing.
\end{abstract}

Keywords: Passing, Game, Passing, Accuracy

\begin{abstract}
Abstrak
Penelitian ini bertujuan untuk mengetahui latihan apakah yang lebih berpengaruh antara latihan mengatur operan dan latihan mengatur permainan terhadap ketepatan passing dalam permainan sepakbola pada Siswa Ekstrakurikuler Sepakbola SD Swasta Al Wasliyah 30 Martubung Medan Tahun 2021. Partisipan penelitian ini sebanyak 20 siswa dengan rentang usia 10-12 tahun. Desain penelitian yaitu pre-test two group experimental design. Instrumen penelitian ini adalah tes ketepatan passing dalam sepabola. Analisis data secara deskriptif kuantitatif, dengan membandingkan perbedaan hasil pretest dan postest. Hasil penelitian dalam bentuk analisis dua hipotesis penelitian. Analisis hipotesa pertama dari data pre-test dan post-test ketepatan passing bola kelompok latihan pass according diperoleh $t_{\text {hitung }}=6,86$. Dari daftar distribusi $t$ dengan menggunakan peluang $1-1 / 2 \alpha=0,975$ dengan $d k n-1=9$
\end{abstract}


diperoleh harga $t(0,975)=2,26$. Dalam kriteria pengujian hipotesa dinyatakan bahwa pada $t_{\text {hitung }}>t_{\text {tabel }}$ dengan $\alpha=0,05$ maka Ho diterima Ha ditolak. Analisis hipotesa kedua dari data pre-test dan post-test ketepatan passing bola kelompok latihan Mengatur Operan diperoleh $t_{\text {hitung }}=5$ 53. Dari daftar distribusi $t$ dengan menggunakan peluang $1-1 / 2 \alpha=0,975$ dengan $d k n-1=9$ diperoleh harga $t(0,975)$ $=2,26$. Dalam kriteria pengujian hipotesa dinyatakan bahwa pada $t_{\text {hitung }}>t_{\text {tabel }}$ dengan $\alpha=0,05$ maka Ho ditolak Ha diterima. Maka dapat disimpulkan dengan menggunakan bentuk latihan mengatur operan dan mengatur permainan dapat meningkatkan ketepatan passing dalam permainan sepakbola pada Siswa Ekstrakurikuler Sepakbola SD Swasta Al Wasliyah 30 Martubung Medan Tahun 2021. Penelitian ini memberikan kontribusi pada penelitian berikutnya dengan dapat menggunakan variabel lainnya sebagai treatment dalam ketepatan passing sepakbola.

Kata Kunci: Operan, Permainan, ketepatan, passing

\section{Introduction}

The development and development of sports in Indonesia is an effort to improve the physical health of the entire community, fertilize character and sportsmanship and improve sports achievement and cultivate the community (Azizah \& Sudarto, 2021; Irawan \& Limanto, 2021; Sutopo \& Misno, 2021). Especially among teenagers, because at this age is considered the most suitable to develop talent and potential to become an accomplished athlete. In national football, there are still early childhood or beginners who have high motivation for the sport of football but do not have many opportunities to get more optimal coaching (Burhaein, Ibrahim, \& Pavlovic, 2020; Tarista \& Jayadi, 2017; Widiyono \& Mudiono, 2021). So based on this, sports people, especially in the football branch, established football schools so that they can educate the younger generation, especially beginners to become reliable football players.

Passing is one of the basic techniques that every player needs. On a flat field and a small field size requires hard and accurate passing because the ball is sliding parallel to the player's heel (Adhie, 2020; Mustofa, Mansur, \& Burhaein, 2019; Purnomo, Tomoliyus, \& Burhaein, 2019). Passing ability becomes a must for a football player. The ability to pass in football is a very important aspect because with the right and accurate passing then in passing the ball to friends will be easily accepted and mastered, so that the ball is not easily lost or seized by the opponent (Bimanggara \& Mansur, 2020; Prasetyo, 2019). With good passing ability with few mistakes can make a game even more interesting to watch.

In improving one's passing ability, there is also a variety in the practice of passing and kicking the ball. Variations in this exercise must be created by the coach so as to eliminate saturation for athletes, let alone exercise for a long period of time (Bozkurt \& Kucuk, 2018; Duval \& Rompuy, 2016). The lack of variety of exercises can make players less able to master basic passing techniques. A targeted exercise program by applying varied basic technique training methods and physical exercise methods combined with games, the goal is that students are not saturated during training. With 1 week 3 times practice it is expected that SSB students can more quickly develop in playing football.(Bompa \& Buzzichelli, 2019; Zago et al., 2015).

One form of practice for the optimization of operand ability is the practice of regulating passes by organizing the game (Prasetyo, 2019; Zago et al., 2015). This exercise is done to improve the ability to pass as well as to improve the ball control ability of the player who does it. This 
exercise can support the player's ability in ball feeling when going to pass the ball to his partner, the extent of the passing power that will be done with the existing distance (Bahtra, Asmawi, \& Dlis, 2020; Phytanza, Burhaein, Sukoco, \& Ghautama, 2018). The advantages of this exercise are very easy to do because each player only directs the ball that will be passed to colleagues with dynamic motion.

Young players at an early age become very physically strong and mature, so the scope of their passing technique can be expanded. They should spend a lot of time honing techniques. They also need to undergo drill practice with opponents, so as to learn where and when to apply the technique of passing the ball in the actual match (Ardian, Suharjana, \& Burhaein, 2019; Cook, 2015; Widodo \& Najibuzzamzam, 2021). Young players of this age also need to be encouraged to practice techniques they have not mastered. They often encounter difficulties and only practice techniques that they managed to master in the early days of playing football. Coaches must be patient, persistent and creative when handling young players who practice passing the ball, which is a vital skill in the game.

From the results of preliminary studies through initial observations made by researchers, it was found that students in passing there are still obstacles to the technique of accuracy of passing and still need to be improved again to be better. This can be seen from the results of preliminary tests of the accuracy of passing the ball obtained by students, where the average test results of the accuracy of the player's ball passing after being included in the table of assessment norms are in the categories Sufficient (C) and Medium (S).

To improve the accuracy of passing the ball, a new exercise must be found that will be applied in the exercise. The use of new exercises becomes an important element to increase the effectiveness of exercise. To that end researchers tried to conduct research on: "Differences in the Influence of Practice Regulating Passes By Regulating The Game Against The Accuracy of Passing In Football Games In Private Elementary School Football Extracurricular Students Al Wasliyah 30 Martubung Medan Year 2021".

\section{Research Methodology}

\subsection{Participants}

The determination of study participants noticed some of the first elements are populations. Population is the whole subject of the study. The population in this study is all Extracurricular Students of Al Wasliyah Private Elementary School Football 30 Martubung Medan in 2021 which amounted to 22 people. The next criterion is the determination of the sample to be used as a study participant. The sample is part of the entirety of the research object that is considered to represent the entire population. This sampling is done by purposive random sampling (Burhaein, Tarigan, Budiana, Hendrayana, \& Phytanza, 2021; Fraenkel, Wallen, \& Hyun, 2012) . The criteria used to eliminate the population include active students and willing to undergo the entire training program that will be given. So that the final results who were participants in this study as many as 20 students with an age range of 10-12 years.

\subsection{Research Design}

This research is quantitative research. This type of research is experimental, using the selection of designs that are pre-test two group experimental design (Fraenkel et al., 2012). The design of this study can be seen in Table 1 . 
Sports Education Study Program, University of Ma'arif Nahdlatul Ulama Kebumen

Table 1. Pre-test research design two group experimental design

\begin{tabular}{cccc}
\hline Pretest & Matching & Treatment/Training & Posttest \\
\hline \multirow{2}{*}{$\mathrm{T}_{1}$} & Group A & $\mathrm{X}_{1}$ & \multirow{2}{*}{$\mathrm{T}_{2}$} \\
& Group B & $\mathrm{X}_{2}$ & \\
\hline
\end{tabular}

Information:

$\mathrm{T}_{1}=$ Pretest (Test passing to the wall)

$\mathrm{X}_{1}=$ Set up Operands

$\mathrm{X}_{2}=$ Set up the Game

$\mathrm{T}_{2}=$ Posttest (Test passing to the wall)

As outlined earlier that this study takes the form of experiments (treatment). Before being given treatment, the sample conducted an initial test (Pre-test) using test passing to the wall, after which the sample was given the treatment as planned, the sample was divided with two groups according to the techniques used, namely group A and group B. Group A was treated with the exercise Of Organizing Operas and group B with the practice of Organizing Games. This treatment lasts for 6 weeks with a volume of exercise 3 times a week. After being given treatment, then held a final test (Post-test) to see, there is no influence of this form of exercise.

\subsection{Instrument}

Intsrument this study is a test of the ball's passing ability. This test has been validated and tested for reliability. Test of passing ability of the ball adopted from the test developed by Said (1977). The facilities and infrastructure required in this measurement include the football field, ball, whistle, cone, stationery, and stopwatch. For more details on the passing test to the wall, it can be seen in Figure 1.

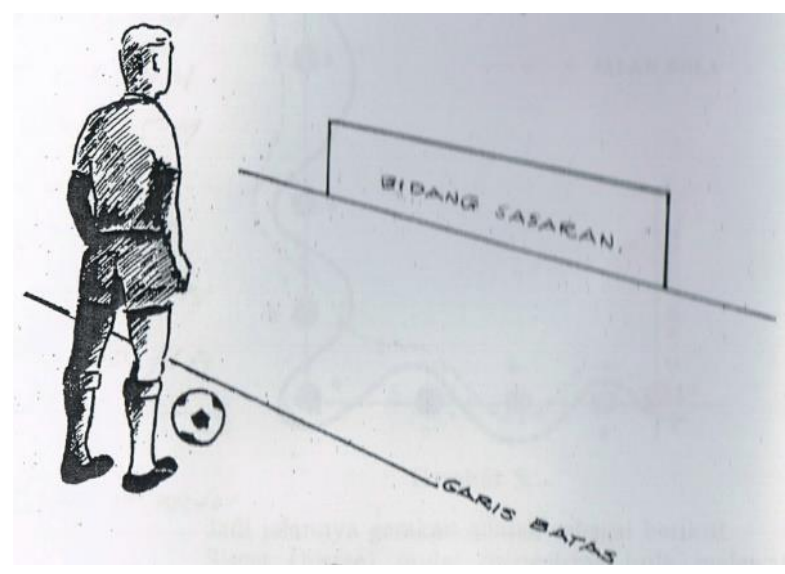

Figure 1. Football Skills Test

(Said, 1977) 


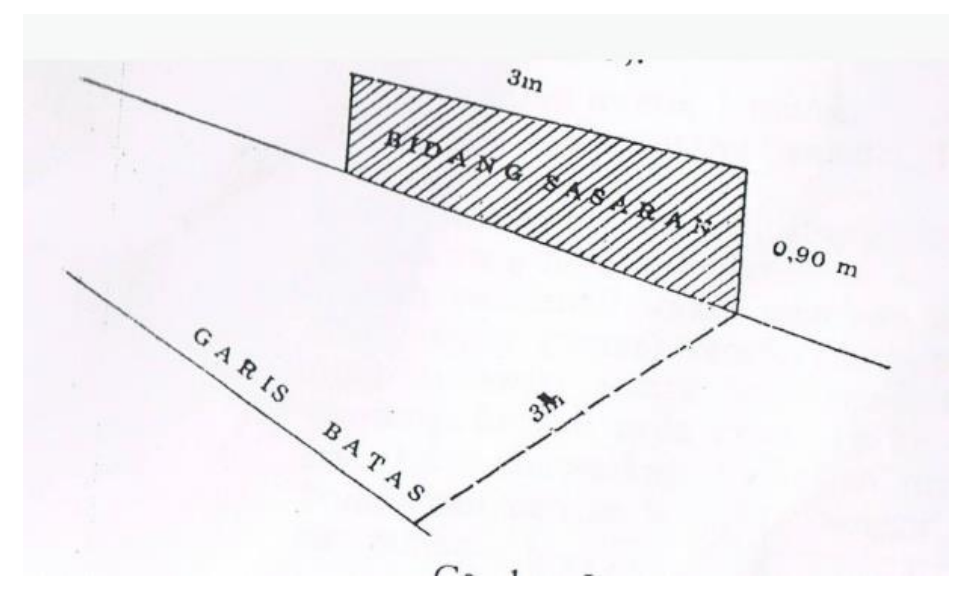

Figure 2. Passing Test Field

(Said, 1977)

\subsection{Data Collection Techniques}

The collection of research data is by taking the initial test data and the final test. There are things that must be considered in the implementation of the test, so that data retrieval can be optimal. The student (testee) stands behind the boundary line, the ball is placed in front of his feet, ready to punt. Then the time taker members "START" and run the stopwatch. Students (testee) immediately punted towards the bounce wall. The bounce of the ball was stopped and briefly held and immediately kicked back towards the wall. This is done repeatedly for 10 seconds. When punting and stopping the ball, the student or testee must stay behind the line. If the student or testee is unable to stop and hold the ball, even the ball bounces away, the student or testee must take it back and start playing the ball again, until the specified time limit.

\subsection{Data Analysis}

Analysis of this research data using a quantitative descriptive approach (Fraenkel et al., 2012; Phytanza, Burhaein, \& Pavlovic, 2021). Description data that is owned is range, average value, standard deviation, difference in average, different standard deviation, and combined standard deviation. This description data is then compared between the pretest and postest data to see how much of a difference each data has. The data analysis in this study was assisted using a statistical application, the IBM 24 SPSS.

\section{Results and Discussion}

\subsection{Resuts}

The results of tests and measurements conducted in the field are the findings of research conducted for 6 weeks. It is done to reveal the truth of the hypothesis that has been submitted. Test results and measurements that have been processed through statistical formulas show the following data descriptions: 
Sports Education Study Program, University of Ma'arif Nahdlatul Ulama Kebumen Table 1. Pre-Test and Post-Test Results

\begin{tabular}{lrrrr}
\hline \multirow{2}{*}{ Data Description } & \multicolumn{3}{c}{ Improved accuracy of passing in the game of football } \\
\cline { 2 - 5 } & \multicolumn{2}{c}{ Pass Accourding } & \multicolumn{2}{c}{ Set up the Game } \\
\cline { 2 - 5 } & Pre-Test & Post-Test & Pre-Test & Post-Test \\
\hline Range & $4-2$ & $6-4$ & $4-2$ & $6-4$ \\
\hline Average Value & 3 & 5,3 & 3,1 & 5,4 \\
\hline Raw Deviation & 0,81 & 0,82 & 0,87 & 0,69 \\
\hline Average Difference & \multicolumn{3}{c}{2,3} \\
\hline Different Standard Deviations & \multicolumn{3}{c}{1.05} \\
\hline Combined Raw Deviation & \multicolumn{2}{c}{0.06} \\
\hline
\end{tabular}

Based on the results of pre-tests in the practice group Set Passes against improving the accuracy of passing in football games with $n=10$ obtained a range between 4-2 with an average of 3 and a standard deviation of 0.81 .Based on post-test results with $n=10$ obtained between $6-4$ with an average of 5.3 and a standard deviation of 0.82 . From the average pre-test and post-test obtained a difference value of 2.3 with a difference of 1.05.Based on the results of pre-tests in the practice group Set The Game against the increase in the accuracy of passing in football with $n=10$ obtained a range between $4-2$ with an average of 3.1 and a standard deviation of 0.87 .

Based on post-test results with $n=10$ obtained between 6-4 with an average of 5.4 and a raw deviation of 0.69 From the pre-test and post-test average obtained a difference of 2.3 with a difference of 1.33.Based on the processing of final data between the exercise group Set Operan with the practice group Set the Game against the increase in the accuracy of passing in football games obtained a combined standard deviation value of 0.06 .

\subsection{Discussion}

Based on the results of the first hypothesis test showed that there was a significant influence between pre-test and post-test in the practice group Set Passes to improve the accuracy of passing in football games In Extracurricular Students Of Private Elementary School Al Wasliyah 30 Martubung Medan In 2021. From the results of the second hypothesis test showed that there was a significant influence between pre-test and post-test in the practice group Set Game to improve the accuracy of passing in football games In Extracurricular Students Of Private Elementary School Al Wasliyah 30 Martubung Medan In 2021. This is achieved because of several factors including the motivation of the samples who are good in doing exercises and running programs, long training time, good mastery of techniques and mastery of techniques that are evenly distributed between samples.

Based on the results of the second hypothesis test showed that there was a significant influence between pre-rest and post-test on the Practice Group Set Game towards improving the accuracy of passing in football games in The Extracurricular Students of Private Elementary School Al Wasliyah 30 Martubung Medan In 2021. This is achieved because of several factors including the practice of Organizing Passes with the practice of Organizing Games and the motivation of the samples in doing both forms of this exercise and running the program well.

Based on the results of the third hypothesis shows that the practice of Arranging Passes is no greater than the practice of Arranging Games towards improving the accuracy of passing in 
football games in The Private Elementary School College Student Al Wasliyah 30 Martubung Medan in 2021. Practice Setting The Game is more favored than the practice of Arranging Passes.

Both of these are because from the third hypothesis only see which is greater influence than the two free variables, namely Regulating Passes and Arranging Games against bound variables, namely improving the accuracy of passing in football games in Private Elementary School Extracurricular Students Al Wasliyah 30 Martubung Medan In 2021.Based on the above explanation it was concluded that the practice of Regulating Passes and Arranging Games can be done to improve accuracy. passing in a football game in a football game.

Passing drills in various forms (regulating passes \& regulating the game) are useful for practicing the accuracy of passing and the player's ability to receive or control the ball (Suzianto \& Damanik, 2014; Widiyono \& Mudiono, 2021). The advantage of this exercise is to improve the accuracy of passing with the practice of using goals, where the target is not only fixed but also changed (Huijgen, Elferink-Gemser, Post, \& Visscher, 2010). So that the player is not focused on the target in one place only. As well as in this exercise can improve the concentration and calmness of players when passing while improving coordination between the legs and eyes.

Players in carrying out this exercise, must be serious in order to be able to pass the ball properly towards friends. The increasing ability of passing accuracy may be influenced by ease of implementation. Because each player only directs the ball to be passed to a colleague who is always straight in front of him, but this training model is less effective because the training child is easily saturated, so the stimulation to be serious in doing the exercise will affect the improvement of the ability of passing accuracy.

The results of this study are supported by previous research. Previous research was conducted by Muchtar (2015). The results of the study are relevant to this study. As for the results of the study Muchtar (2015) Is to produce the conclusion there are differences and influence of practice to regulate passes by regulating the game to the accuracy of passing in the game of football in athletes aged 12-13 years SSB PORTIS SAENTIS PERCUT SEI TUAN Year 2015.

\section{Conclusion}

Based on the results of hypothesis testing, the following conclusions were drawn: Exercise In Regulating Passes has a significant influence on improving the accuracy of passing in football games in The Extracurricular Students of Private Elementary School Al Wasliyah 30 Martubung Medan Year 2021.Practice Organizing Games exerts a significant influence on the improvement of passing accuracy in football games in Extracurricular Students Of Private Elementary School Al Wasliyah 30 Martubung Medan Year 2021.The Practice of Regulating Passes is no greater than the Practice of Regulating the Game towards the improvement of the accuracy of passing in football games in The Extracurricular Students of Private Elementary School Al Wasliyah 30 Martubung Medan In 2021. This research contributes to subsequent research by being able to use other variables as treatment in the accuracy of football passing.

\section{References}

Adhie, O. C. (2020). the Effectiveness of Problem-Based Learning Approach in the Teaching of Hang Style Long Jump. Jurnal Ilmiah Bina Edukasi, 13(2), 24-30. 
Sports Education Study Program, University of Ma'arif Nahdlatul Ulama Kebumen https://doi.org/10.33557/jedukasi.v13i2.1152

Ardian, R., Suharjana, S., \& Burhaein, E. (2019). Effect of progressive and repetitive part methods against the accuracy of kicking in football extracurricular students. ScienceRise, 1(7), 40-44. https://doi.org/10.15587/2313-8416.2019.174318

Azizah, A. R., \& Sudarto, E. P. (2021). Minat Mengikuti Ekstrakurikuler Bola Voli Siswa Smp Negeri 3 Satu Atap Karangsambung Kecamatan Karangsambung Tahun Ajaran 2019/2020. JUMORA: Jurnal Moderasi Olahraga, 1(01), 35-44. https://doi.org/10.53863/mor.v1i01.132

Bahtra, R., Asmawi, M., \& Dlis, F. (2020). Improved VO 2Max: The Effectiveness of Basic Soccer Training at a Young Age. International Journal of Human Movement and Sports Sciences, 8(3), 97-102. https://doi.org/10.13189/saj.2020.080304

Bimanggara, Y. L., \& Mansur. (2020). Completeness of Football School (SSB) Facilities and Infrastructures: Survey for Ages Group 8-20 Years in Yogyakarta City. Physical Education and Sport Through the Centuries, 7(1), 72-82. https://doi.org/10.2478/spes-2020-0006

Bompa, T. O., \& Buzzichelli, C. (2019). Periodization Theory and Methodology of Training (Sixth). United States.

Bozkurt, S., \& Kucuk, V. (2018). Comparing of Technical Skills of Young Football Players According to Preferred Foot. International Journal of Human Movement and Sports Sciences, 6(1), 19-22. https://doi.org/10.13189/saj.2018.060103

Burhaein, E., Ibrahim, B. K., \& Pavlovic, R. (2020). The Relationship of Limb Muscle Power, Balance, and Coordination with Instep Shooting Ability: A Correlation Study in Under-18 Football Athletes. International Journal of Human Movement and Sports Sciences, 8(5), 265 270. https://doi.org/10.13189/saj.2020.080515

Burhaein, E., Tarigan, B., Budiana, D., Hendrayana, Y., \& Phytanza, D. T. P. (2021). Physical Activity Level of Students with Disabilities during COVID-19 Pandemic. Jurnal Pendidikan Jasmani Dan Olahraga, 6(2), 19-21. https://doi.org/10.17509/jpjo.v6i2.38547

Cook, M. (2015). Soccer Training: Games, Drills and Fitness Practices. London: Bloomsbury Publishing.

Duval, A., \& Rompuy, B. Van. (2016). The FIFA regulations on the status and transfer of players: Transnational law-making in the shadow of Bosman. Netherland: Springer.

Fraenkel, J. R., Wallen, N. E., \& Hyun, H. H. (2012). How to design and evaluate research in education. New York: Mc Graw Hill.

Huijgen, B. C. H., Elferink-Gemser, M. T., Post, W., \& Visscher, C. (2010). Development of dribbling in talented youth soccer players Technical skills aged 12-19 years: A longitudinal study. Journal of Sports Sciences, 28(7), 689-698. https://doi.org/https://doi.org/10.1080/02640411003645679

Irawan, Y. F., \& Limanto, D. (2021). Pengaruh Kecerdasan Emosi dan Kesiapan Diri Terhadap Pertandingan Pada Pemain Walet Muda Futsal Academy Kebumen Tahun 2020. JUMORA: Jurnal Moderasi Olahraga, 1(01), 18-26. https://doi.org/10.53863/mor.v1i01.130

Muchtar, M. (2015). Perbedaan Pengaruh Latihan Mengatur Operan dengan Mengatur Permainan terhadap Ketepatan Passing dalam Permainan Sepakbola pada Atlet Usia 12-13 Tahun SSB PORTIS SAENTIS PERCUT SEI TUAN Tahun 2015. Universitas Medan.

Mustofa, F., Mansur, M., \& Burhaein, E. (2019). Differences in the effect of learning methods massed practice throwing and distributed distributed practice on learning outcomes skills for the accuracy of top softball. Journal of Sport Sciences Researches, 4(2), 213-222. https://doi.org/10.25307/jssr.571793 
Phytanza, D. T. P., Burhaein, E., \& Pavlovic, R. (2021). Gross Motor Skills Levels in Children with Autism Spectrum Disorder during the COVID-19 Pandemic. International Journal of Human Movement and Sports Sciences, 9(4), 738-745. https://doi.org/10.13189/saj.2021.090418

Phytanza, D. T. P., Burhaein, E., Sukoco, S., \& Ghautama, S. W. (2018). Life Skill Dimension based on Unified Sports Soccer Program in Physical Education of Intellectual Disability. Yaşam Becerileri Psikoloji Dergisi, 2(4), 199-205. https://doi.org/https://doi.org/10.31461/ybpd.453865

Prasetyo, Y. T. (2019). Pengaruh metode latihan lari percepatan dan lari interval terhadap peningkatan dribbling pada pemain sepakbola ku 14 tahun di ssb pandawa effect of training methods to run acceleration and run intervals towards upgrading dribbling to my 14-year-old footba. Pend. Kepelatihan Olahraga, 8(8), 1-13.

Purnomo, I. D., Tomoliyus, T., \& Burhaein, E. (2019). Development of Learning Activities Playing a Ball on a Goal To Improve Manipulative Skills For Lower Class Students. Proceedings of the 1st International Conference on Science and Technology for an Internet of Things. https://doi.org/10.4108/eai.19-10-2018.2281716

Said, H. (1977). Tes Keterampilan Bermain Sepakbola. Jakarta: Departemen Pendidikan dan Kebudayaan Indonesia.

Sutopo, W. G., \& Misno. (2021). Analisis Kecepatan Tendangan Sabit Pada Pesilat Remaja Perguruan Pencak Silat Tri Guna Sakti Di Kabupaten Kebumen Tahun 2020. JUMORA: Jurnal Moderasi Olahraga, 1(01), 27-34. https://doi.org/10.53863/mor.v1i01.131

Suzianto, \& Damanik, S. (2014). Penerapan Model Problem Based Learning Dalam Meningkatkan Hasil Belajar Passing Bawah Bola Voli Siswa Kelas Viii-2 Smp Negeri 27 Medan Tp. 2018/2019. Jurnal Ilmu Keolahragaan, 18(1), 14-24.

Tarista, R., \& Jayadi, I. (2017). Survei Keterampilan Teknik Dasar Permainan Sepakbola (Studi pada Ssb Rheza Mahasiswa Ku-14 Tahun). Jurnal Prestasi Olahraga, 1(1), 1-14.

Widiyono, I. P., \& Mudiono. (2021). Keterampilan Dasar Futsal Peserta Ektrakurikuler di SMK Ma'arif 1 Kebumen Tahun Ajaran 2019/2020. JUMORA: Jurnal Moderasi Olahraga, 1(01), 10-17. https://doi.org/10.53863/mor.v1i01.129

Widodo, P., \& Najibuzzamzam, A. (2021). Perbandingan Model Pembelajaran Daring Dan Tatap Muka Penjaskes Mts Darussa'adah Pada Masa Pandemi Tahun Ajaran 2019/2020. JUMORA: Jurnal Moderasi Olahraga, 1(01), 1-9. https://doi.org/10.53863/mor.v1i01.128

Zago, M., Piovan, A. G., Annoni, I., Ciprandi, D., Iaia, F. M., Sforza, C., ... Sforza, C. (2015). Dribbling determinants in sub-elite youth soccer players Click for updates Dribbling determinants in sub-elite youth soccer players. Journal of Sports Sciences, 34(5), 411-419. https://doi.org/10.1080/02640414.2015.1057210 